\title{
Duodenal bacterial overgrowth during treatment in outpatients with omeprazole
}

\author{
Michael Fried, Hans Siegrist, Reno Frei, Florian Froehlich, Philippe Duroux, Joel Thorens, \\ André Blum, Jacques Bille, Jean J Gonvers, Klaus Gyr
}

\begin{abstract}
The extent of duodenal bacterial overgrowth during the pronounced inhibition of acid secretion that occurs with omeprazole treatment is unknown. The bacterial content of duodenal juice of patients treated with omeprazole was therefore examined in a controlled prospective study. Duodenal juice was obtained under sterile conditions during diagnostic upper endoscopy. Aspirates were plated quantitatively for anaerobic and aerobic organisms. Twenty five outpatients with peptic ulcer disease were investigated after a $5.7(0.5)$ weeks (mean (SEM)) treatment course with 20 mg (nine patients) or $40 \mathrm{mg}$ (16 patients). The control group consisted of 15 outpatients referred for diagnostic endoscopy without prior antisecretory treatment. No patient in the control group had duodenal bacterial overgrowth. In the omeprazole group bacterial overgrowth $\left(\geqslant 10^{5} \mathrm{cfu} / \mathrm{ml}\right.$ ) was found in 14 $(56 \%)$ patients $(p=0.0003)$. The number of bacteria $\left(\log _{10}\right)$ in duodenal juice in patients treated with omeprazole was distinctly higher (median 5.7; range $<2-8.7$ ) when compared with the control group (median $<2$; range $<2-5.0 ; p=0 \cdot 0004)$. As well as orally derived bacteria, faecal type bacteria were found in seven of 14 and anaerobic bacteria in three of 14 patients. Bacterial overgrowth was similar with the two doses of omeprazole. These results indicate that duodenal bacterial overgrowth of both oral and faecal type bacteria occurs often in ambulatory patients treated with omeprazole. Further studies are needed to determine the clinical significance of these findings, particularly in high risk groups during long term treatment with omeprazole. (Gut 1994; 35: 23-26)
\end{abstract}

Departments of

Gastroenterology and
Microbiology, University

Hospital, Lausanne,

Switzerland

M Fried

H Siegrist

F Froehlich

P Duroux

J Thorens

A Blum

J Bille

J J Gonvers

Outpatient Clinic and Department of

Microbiology, University

Hospital, Basel,

Switzerland

R Frei

K Gyr

Correspondence to:

Dr Michael Fried, Policlinique médicale universitaire, Rue

César Roux 19, 1005

Lausanne, Switzerland.

Accepted for publication 19 May 1993 short period (two weeks). Therefore, no conclusions can be drawn from this study regarding patients with peptic ulcer disease treated with standard doses of omeprazole during conventional treatment periods (four to eight weeks). Furthermore, bacterial colonisation of the duodenum was not investigated in this study. Thus it is not known whether small bacterial overgrowth occurs during omeprazole treatment.

We therefore examined the bacterial content of the duodenal juice of patients with peptic ulcer disease treated with omeprazole in a controlled prospective study. A novel technique for sterile aspiration of duodenal juice during endoscopy was used.

\section{Patients and methods}

\section{PATIENTS}

The study was performed on 25 outpatients (mean age 53.4; range 25 to 83 years; 9 women). Endoscopy revealed the presence of gastric ulcers, (three), duodenal ulcers (two), pyloric ulcers (two), gastric and/or duodenal erosions (three), Barrett oesophagus (one), and reflux oesophagitis (14 patients). The patients were treated with $20 \mathrm{mg}$ (nine patients for $4 \cdot 7(2 \cdot 1)$ weeks (mean (SEM)) or $40 \mathrm{mg}$ (16 patients for $6.2(2.4)$ weeks) of omeprazole, the whole daily dose being taken with breakfast. All patients were investigated one day after the end of treatment. Thus the last omeprazole capsules were taken 24-28 hours before endoscopy. Another 15 patients (mean age 46.0 ; range 25 to 73 years; 8 women; difference from omeprazole group NS) referred to the outpatient clinic for a routine diagnostic endoscopy with suspected peptic ulcer disease were examined as a control group. These patients had not taken $\mathrm{H}_{2}$ antagonists, omeprazole, or other antisecretory drugs within 10 days before endoscopy. In this untreated control group endoscopy showed gastric ulcer (one), duodenal ulcer (one), pyloric ulcer (one), reflux oesophagitis (one), Barrett oesophagus (one), Mallory-Weiss tear (one), gastric and/or duodenal erosions (three), and gastric polyp (one patient). Endoscopy findings were normal in five patients. Patients treated with omeprazole were asked about the presence of loose stools or diarrhoea in the last weeks before endoscopy.

Neither group of patients had received antibiotics within one month before the examination. All endoscopic examinations were performed for clinical indications and the patients were informed that material was to be aspirated for the study. The study was approved by the local ethics committee. 


\section{SAMPLING PROCEDURE}

An Olympus GIF-Q20 endoscope was used for all investigations, and a double sheathed plastic wash pipe (Mauch, Münchenstein, Switzerland) was used to collect the aspirates by a previously reported technique. ${ }^{7}$ The pipe was constructed by passing one teflon coated plastic tube (diameter $1 \mathrm{~mm}$ ) inside another (diameter $2 \cdot 3$ $\mathrm{mm}$ ). The end of the outer tube was covered by a thin rubber plug vulcanised into its tip, so that the interior of the outer tube containing the inner tube remained sterile until the rubber plug was pierced by pushing the inner tube out of the outer tube. After assembling both tubes and vulcanisation of the rubber plug into the tip of the outer tube, the whole assembly was sterilised by autoclaving for 20 minutes at $120^{\circ} \mathrm{C}$.

All endoscopy procedures were performed after an overnight fast. The patients were asked not to brush their teeth in the morning before endoscopy. No local anaesthesia was used. The patients were sedated with 2.5 to $5 \mathrm{mg}$ midazolam (Dormicum) given intravenously. The microbiological samples were obtained under endoscopic visualisation about $20 \mathrm{~cm}$ beyond the pylorus. Care was taken to use minimal air insufflation during endoscopy before obtaining the specimens to maintain the intraluminal environment as much as possible. When the collection site was chosen, the sterilised double sheathed wash pipe was passed through the suction channel. After the overtube had cleared the tip of the endoscope, the inner tube was pushed forward so that its tip pierced the rubber stopper at the tip of the outer tube and emerged. About $2 \mathrm{ml}$ of aspirate were collected in a sterile syringe and immediately transferred to an anaerobic transport vial (Port-A-Germ, BioMérieux, France).

\section{BACTERIOLOGICAL CULTURE}

The microbiologists who cultured the duodenal aspirates had no knowledge of the clinical or endoscopical findings; nor were they informed about the treatment regimen of the patients. The contents of the transport vial were measured (volume) and plated for both aerobic and anaerobic organisms. The samples were serially diluted with phosphate buffer containing $1 \%$ peptone. Aerobic cultures were grown by plating the samples on the following media: $5 \%$ sheep blood agar, MacConkey agar, phenyl ethyl alcohol agar, and Sabouraud glucose agar containing gentamicin and chloramphenicol. Anaerobic cultures were grown by inoculating the following solid media: blood agar containing sheep blood supplemented with cysteine and vitamin $\mathrm{K} 1$, neomycin agar, and vancomycin/ nalidixic acid agar. Media were incubated for a minimum of 72 hours with a first reading at 24 hours for aerobic growth and 48 hours for anaerobes. Bacteria were identified by standard methods to species level or, where appropriate, to genus level only. Bacterial numbers were determined by a colony count of the individual bacterial morphologies and expressed in exponential numbers per $\mathrm{ml}$ of clinical specimen.

After aerobic and anaerobic incubation, cultures were considered positive for bacterial overgrowth if the total count of bacteria was $\geqslant 10^{5} / \mathrm{ml}$. Cultures were considered negative for bacterial overgrowth when the total bacterial count was $<10^{5} / \mathrm{ml}$.

\section{STATISTICAL EVALUATION}

Values are given as medians (range). Statistical analysis of the data was by Fisher's exact test to compare the number of patients with and without bacterial overgrowth after treatment with omeprazole and without treatment. Bacterial counts were logarithmically transformed for statistical evaluation. The bacterial counts in the duodenal juice in the two groups were compared with the non-parametric Mann-Whitney U test. Differences were considered significant with $\mathrm{p}$ values $<0.05$.

\section{Results}

Treatment with omeprazole caused bacterial overgrowth $\left(\geqslant 10^{5} \mathrm{cfu} / \mathrm{ml}\right)$ of the duodenum in 14 of 25 patients $(56 \%)$. The dose of omeprazole did not influence the frequency of bacterial overgrowth. Thus a similar proportion of the patients exhibited duodenal bacterial overgrowth with 20 mg (five of nine patients) compared with $40 \mathrm{mg}$ (nine of 16 patients). In the untreated control group no patient showed a significant bacterial colonisation of the duodenum (none of 15 patients). This difference from the group of patients treated with omeprazole was very highly significant $(p=0.0003)$. The median number of bacterial counts was 5.7 (range $<2$ to 8.7 ) in the omeprazole group compared with $<2$ (range $<2$ to $4 \cdot 8)$ in the controls $(\mathrm{p}=0.0004)$.

Figure 1 shows the type of bacteria $\left(\geqslant 10^{4} \mathrm{cfu} /\right.$ $\mathrm{ml}$ ) identified in patients treated with omeprazole who had bacterial overgrowth. Haemolytic (12 patients) and non-haemolytic (10 patients) streptococci were mostly found. Gram negative Enterobacteriaceae, such as Klebsiella species (five patients), Escherischia coli (one patient) as well as Pseudomonas species (two patients), enterococci (one patient), and Bacteroides species (one patient) were identified in nine patients, and anaerobes in three patients (Bacteroides species in one patient and Clostridium species in two patients). In seven of 14 patients with bacterial overgrowth faecal type bacteria (Escherischia coli, Clostridium species, Bacteroides species, enterococci, and Klebsiella species) were found, whereas only oral and pharyngeal type bacteria were identified in the other seven patients.

Two patients treated with omeprazole who had bacterial overgrowth and one patient without overgrowth reported loose stools or diarrhoea.

\section{Discussion}

Gastric acid is a major defence factor against the bacterial colonisation of the small bowel and thus contributes to the prevention of bacterial overgrowth syndromes and intestinal infection..$^{1-489}$ In the past few years omeprazole - a drug with a high potency to inhibit gastric acid secretion has been introduced into clinical practice. 


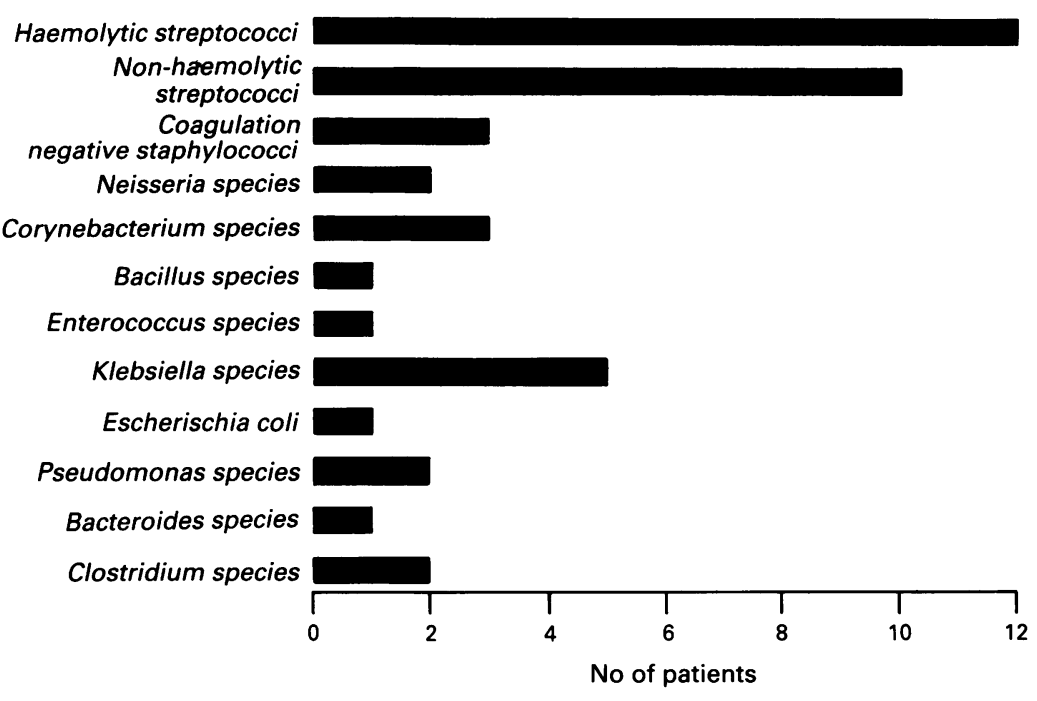

Type of bacteria $\left(\geqslant 10^{4} \mathrm{cfu} / \mathrm{ml}\right)$ in duodenal fluid of patients with duodenal bacterial overgrowth after treatment with omeprazole (number of patients with respective species).

Omeprazole may theoretically cause bacterial colonisation of the upper small intestine by its pronounced inhibition of gastric acid secretion. Despite this hypothetical risk, no studies have been performed to investigate the bacterial flora of the upper small intestine during treatment with omeprazole.

This study was motivated by three considerations: Firstly, omeprazole diminishes gastric acid secretion more than $\mathrm{H}_{2}$ antagonists ${ }^{5}$ and is thus more likely to produce duodenal bacterial overgrowth. Secondly, we have previously shown that although omeprazole raises intragastric $\mathrm{pH}$ above 4 for prolonged periods, the $\mathrm{pH}$ is less than 3 for several hours in each day. ${ }^{10}$ Therefore, the question of whether duodenal bacterial overgrowth occurs during omeprazole treatment cannot be decided by theoretical considerations alone. ${ }^{3}$ Thirdly, the methods used so far to examine duodenal bacterial overgrowth during antisecretory treatment with $\mathrm{H}_{2}$ antagonists are indirect (breath tests) and lack sensitivity and specificity, ${ }^{11}$ and only direct intubation of the small intestine can provide reliable data about the bacterial flora of the small intestine..$^{3411}$ Our study is therefore the first investigation to examine directly duodenal bacterial overgrowth during antisecretory treatment. Also, it is the first study to examine the bacterial flora of the small intestine in patients treated with omeprazole. By applying endoscopic intubation of the duodenum we found bacterial overgrowth in more than half of the patients treated with $20-40$ mg omeprazole daily for four to eight weeks, a dose and treatment duration applied in everyday clinical routine.

Bacterial colonisation of the stomach and the upper small intestine depends on the degree of the reduction in gastric acid secretion. ${ }^{189} 12-19$ Patients with reduced gastric acid secretion - for example, after vagotomy and antral resection develop gastric ${ }^{18-20}$ and duodenal ${ }^{19}$ bacterial overgrowth if the gastric $\mathrm{pH}$ rises above $4 \cdot 0$. Recent studies have shown that omeprazole diminishes intragastric acidity by more than $90 \%$ in ulcer patients and healthy subjects ${ }^{2122}$ with a median $\mathrm{pH}$ above $3 \cdot 5-4 \cdot 0$ for prolonged periods. ${ }^{10}$ Thus the pronounced inhibition of gastric acid secretion during omeprazole treatment may explain the development of duodenal bacterial overgrowth in most of our patients. The degree of bacterial colonisation was similar with 20 or $40 \mathrm{mg}$, which may be explained by the already profound inhibition of gastric acid secretion $(>90 \%)$ by the lower dose..$^{21} 22$

Conflicting results have been published about gastric bacterial overgrowth during treatment with other antisecretory drugs, in particular $\mathrm{H}_{2}$ antagonists. Several groups found an increased number of intragastric bacteria in patients receiving cimetidine $e^{13-15} 1724-27$ or ranitidine,,$^{1823}$ although other groups were unable to confirm these findings. ${ }^{12829}$ Omeprazole has been reported to cause gastric bacterial overgrowth in healthy volunteers. ${ }^{10}$ Few studies have investigated the incidence of duodenal bacterial overgrowth during treatment with $\mathrm{H}_{2}$ antagonists. ${ }^{30-32}$ Two studies reported no bacterial overgrowth in the small intestine during treatment with cimetidine ${ }^{30}$ and ranitidine. ${ }^{31}$ The $\mathrm{H}_{2}$ breath tests used as the method of assessment has a low sensitivity and specificity, however. ${ }^{11}$ In one case report applying direct tube intubation of the jejunum, bacterial overgrowth was found to be a cause of severe diarrhoea during cimetidine treatment. ${ }^{32}$

Most of the bacteria identified in our study belong to species colonising the oral cavity and pharynx, suggesting a descending route of colonisation. These results are in agreement with those of previous studies in patients treated with $\mathrm{H}_{2}$ antagonists, where mostly bacteria originating from the mouth were identified in gastric contents. ${ }^{13242629}$ Similarly, omeprazole led to gastric colonisation with oral type bacteria in healthy volunteers. ${ }^{6}$ In half of our patients with bacterial overgrowth, however, faecal type bacteria were also found including anaerobes. Thus it seems that omeprazole may also cause ascending colonisation of the upper small intestine.

What are the clinical consequences of duodenal bacterial overgrowth during omeprazole treatment, as shown in this investigation? The design of the study and the small number of patients do not allow us to draw firm conclusions about the frequency of symptoms attributable to small intestinal bacterial overgrowth. Patients were treated with omeprazole for short periods, and few reported side effects; however, the development of clinically significant manifestations of bacterial overgrowth syndromes depends on the presence of anaerobic bacteria in the upper small intestine over prolonged periods. ${ }^{34}$ Anaerobic colonisation can be associated with the development of vitamin B12 deficiency and malabsorption syndromes with steatorrhea, ${ }^{34}$ and recently, omeprazole has been shown to decrease cobalamine absorption..$^{33}$ The risk of bacterial overgrowth syndromes during treatment with omeprazole should therefore be evaluated in prospective controlled studies especially in risk patients with long term omeprazole treatment.

As well as the development of duodenal bacterial overgrowth syndromes, reduced gastric acid secretion during treatment with omeprazole 
may cause a rise in the number of nitrate reducing bacteria in the stomach. This has been claimed to increase the formation of potentially carcinogenic $\mathrm{N}$-nitroso compounds ${ }^{6}$ although we could not confirm these findings in another study. ${ }^{34}$ Furthermore, reduced gastric acid secretion may be responsible for a higher incidence of intestinal infections, ${ }^{19}$ such as salmonellosis, ${ }^{35}{ }^{36}$ cholera, ${ }^{37}$ and parasitic infections. ${ }^{38}$ Such infections have been described in patients treated with cimetidine ${ }^{32} 39$ and ranitidine. ${ }^{36}$ Recently, Salmonella gastroenteritis has been reported in a patient treated with $20 \mathrm{mg}$ omeprazole. ${ }^{40}$ Also, reduced gastric acid secretion during treatment with $\mathrm{H}_{2}$ antagonists has been associated with the occurrence of nosocomial infections, in particular pneumonias, in intensive care units. ${ }^{2341}$ Further studies with high risk patients, such as travellers or patients in intensive care units, are needed to assess these potential risks of omeprazole treatment.

In summary, we found duodenal bacterial colonisation in more than half of the patients treated with $20-40 \mathrm{mg}$ omeprazole for short periods of four to eight weeks. The bacterial flora consisted mainly of oral type bacteria, but in half of the patients faecal type bacteria including anaerobes were also present. The clinical significance of these findings needs to be assessed in controlled prospective studies, particularly during long term omeprazole treatment and in patients belonging to high risk groups.

This study was supported by the Swiss National Science Foundation grant 32.33723.92.

We thank Christian Durussel for excellent technical assistance and Rob Fraser, MD, for editorial assistance.

1 Howden CW, Hunt RH. Relationship between gastric secretion and infection [progress report]. Gut 1987; 28: 96 107.

2 Drasar BS, Shiner M, McLeod GM. Studies on the intestina flora. I. The bacterial flora of the gastrointestinal tract in healthy and achlorhydric persons. Gastroenterology 1969;56: 71-9.

3 Simon GL, Gorbach SL. Intestinal flora in health and disease. Gastroenterology 1984; 86: 174-93.

4 Sherman P, Lichtman S. Small bowel bacterial overgrowth syndrome. Dig Dis 1987; 5: 157-71.

5 Prewett EJ, Hudson M, Nwokolo CU, Sawyerr AFM, Pounder RE. Nocturnal intragastric acidity during and after a period of dosing with either ranitidine or omeprazole. a period of dosing with either ranil
Gastroenterology 1991; 100: 873-7.

6 Sharma BK, Santana IA, Wood EC, Walt RP, Pereira M, Noone $\mathrm{P}$, et al. Intragastric bacterial activity and nitrosation before, during, and after treatment with omeprazole. $B M \mathcal{F}$ 1984; 289: 717-9.

7 Bardhan PK, Gyr K, Beglinger C, Vögtlin J, Frey R, Vischer W. Diagnosis of bacterial overgrowth after culturing proximal small-bowel aspirate obtained during routine upper gastrointestinal endoscopy. Scand $\mathcal{f}$ Gastroenterol 1992; 27: 253-6.

8 Allan Gray JD, Shiner $\mathrm{M}$. Influence of gastric $\mathrm{pH}$ on gastric and jejunal flora. Gut 1967; 8: 574-81.

9 Sarker SA, Gyr K. Non-immunological defense mechanisms of the gut. Gut 1992; 33: 987-93.

10 Viani F, Idström J-P, Emde C, Cederberg C, Fried M, Blum $\mathrm{AL}$, et al. Does omeprazole cause gastric anacidity in healthy AL, et al. Does omeprazole cause gastric anacid

11 Corazza GR, Menozzi MG, Strocchi A, Rasciti L, Vaira D, Lecchini $\mathbf{R}$, et al. The diagnosis of small bowel bacterial overgrowth. Gastroenterology 1990; 98: 302-9.

12 Muscroft TJ, Youngs DJ, Burdon D, Keighley MRB. Cimetidine is unlikely to increase formation of intragastric $\mathrm{N}$-nitroso-compounds in patients taking a normal diet. Lancet 1981; i: 408-10.

13 Hamilton I, Worsley BW, O'Connor HJ, Axon ATR. Effects of tripotassium dicitrato bismuthate (TDB) tablets or cimetidine in the treatment of duodenal ulcer. Gut 1983; 24: 1148-51.

14 Hillman KM, Riordan T, O'Farrell SM, Tabaqchali S. Colonization of the gastric contents in critically ill patients. Crit Care Med 1982; 10: 444-7.

15 Ruddell WS J, Axon ATR, Findlay JM, Bartholomew BA, Hill MJ. Effect of cimetidine on the gastric bacterial flora. Lancet 1980; i: 672-74.

16 Gilman RH, Partanen R, Brown KH, Spira WM, Khanam S, Greenberg B, et al. Decreased gastric acid secretion and bacterial colonization of the stomach in severely malnourished Bangladeshi children. Gastroenterology 1988; 94: 1308-14.

17 Du Moulin GC, Paterson DG, Hedley-Whyte J, Lisbon A. Aspiration of gastric bacteria in antacid-treated patients: a frequent cause of postoperative colonization of the airway. Lancet 1982; i: 242-5.

18 Meyrick Thomas J, Misiewicz JJ, Cook AR, Hill MJ, Smith PLR, Walters CL, et al. Effects of one year's treatment with ranitidine and of truncal vagotomy on gastric contents. Gut 1987; 28: 726-38.

19 Drasar BS, Shiner M. Studies on the intestinal flora. II Bacterial flora of the small intestine in patients with Bacterial flora of the small intestine in pati

20 Enander LK, Nilsson F, Ryden A-C, Schwan A. The aerobic and anaerobic microflora of the gastric remnant more than 15 years after Billroth II resection. Scand $\mathcal{F}$ Gastroenterol 1982; 17: 715-20.

21 Lind T, Cederberg C, Olausson M, Olbe L. 24-Hour intragastric acidity and plasma gastrin after omeprazole treatment and after proximal gastric vagotomy in duodenal ulcer patients. Gastroenterology 1990; 99: 1593-8.

22 Olbe L, Cederberg C, Lind T, Olausson M. Effect of omeprazole on gastric acid secretion and plasma gastrin in man. Scand f Gastroenterol 1989; 24 (suppl): 27-32.

23 Reusser P, Scheidegger D, Buser M, Gyr K, et al. Role of gastric colonization in nosocomial infections and endotoxemia: a prospective study in neurosurgical patients on mechanical ventilation. $\mathcal{F}$ Infect $D$ is $1989 ; 160: 414-21$.

24 Stockbrugger RW, Cotton PB, Eugenides N, Bartholomew BA, Hill MJ, Walters CL. Intragastric nitrites, nitrosamines, and bacterial overgrowth during cimetidine treatsamines, and bacterial overgrow

25 Snepar R, Poporad GA, Romano JM, Kobasa WD, Kaye D. Effect of cimetidine and antacid on gastric microbial flora. Infect Immun 1982; 36: 518-24.

26 Forster A, Niethamer T, Suter P, Pitteloud JJ, Intante F, Ducel G, et al. Influence de la cimétidine sur la croissance bactérienne dans le liquide gastrique. La Nouvelle Press Medicale 1982; 11: 2281-3.

27 Garvey BM, McCambley JA, Tuxen DV. Effects of gastric alkalization on bacterial colonization in critically ill patients. Crit Care Med 1989; 17: 211-6.

28 Stockbrugger RW, Cronstedt J, Dotevall G, Hellner L, Hoffmann P, Hradsky M, et al. The intragastric milieu Hoffmann P, Hradsky M, et al. The intragastric milieu during gastric ulcer treatment with pirenzepine $50 \mathrm{mg}$ bid
cimetidine $400 \mathrm{mg}$ bid. $Z$ Gastroenterol $1988 ; 26: 685-8$.

29 Milton-Thompson GJ, Lightfoot NF, Ahmet Z, Hunt RH. Intragastric acidity, bacteria, nitrite, and $\mathrm{N}$-nitroso compounds before, during, and after cimetidine treatment. Lancet 1982; ii: 1091-5.

30 Bourne JT, Mountford RA, Barry RE. Twice-daily cimetidine does not increase gastric bacterial flora. Postgrad Med $\mathcal{F}$ 1984; 60: 464-6.

31 Armbrecht U, Seeberg S, Stockbrügger RW. Hydrogen $\left(\mathrm{H}_{2}\right)$ breath excretion in peptic disease before and during treatment with ranitidine. Scand $\mathcal{f}$ Gastroenterol 1987; 22: $1211-6$.

32 Ruddell WSJ, Losowsky MS. Severe diarrhoea due to small intestinal colonization during cimtidine treatment. $B M \mathcal{Y}$ intestinal co

33 Marcuard SP, Khazanie. Omeprazole therapy causes cobalamine (vitamin B12) malabsorption. Gastroenterology 1992; 102: A565.

34 Armstrong D, Viani F, Siegrist H, Pignatelli B, Idström JP, Cederberg $\mathrm{C}$, et al. Does omeprazole increase gastric bacterial counts, nitrite or total nitroso compounds in healthy subjects? Gastroenterology 1992: 102: A34

35 Taylor DN, Bied JM, Munro JS, Feldman RA. Salmonella dublin infections in the United States, 1979-1980. F Infect Dis 1982; 146: 322-7.

36 Wickramasinghe LSP, Basu SK. Salmonellosis during treatment with ranitidine. $B M \mathcal{F}$ 1984; $289: 1272$.

37 Toeg A, Berger SA, Battat A, Hoffman M, Yust I. Vibrio cholerae bacteremia associated with gastrectomy. $\mathcal{f}$ Clin Microbiol 1990; 28: 603-4.

38 El Masri SH, Okosdonossian ET, Boulos PD. The clinical significance of gastric acid secretion in bilharzial hepatic

39 Cristiano O, Paradisi F. Can cimetidine facilitate infections by oral route? Lancet 1982; i: 45.

40 Wingate DL. Acid reduction and recurrent enteritis. Lance 1990; i: 222.

41 Driks MR, Craven DE, Celli BR, Manning M, Burke RA Garvin GM, et al. Nosocomial pneumonia in intubated patients given sucralfate as compared with antacids or histamine type 2 blockers. $N$ Engl f Med 1987; 317: 137682. 